\title{
IMAGENS DOS CORPOS INSCRITAS NAS \\ NARRATIVAS DE ALUNOS DO ENSINO MÉDIO: \\ AS (INTER)CORPOREIDADES E O CURRÍCULO
}

- ROBERTA JARDIM COUBE

Universidade Federal Fluminense

- EDA MARIA DE OLIVEIRA HENRIQUES

Universidade Federal Fluminense

RESUMO Este texto é um exercício de sentir, pensar e agir sobre modos outros de lidar com a pesquisa na educação. Valemo-nos da abordagem de pesquisa narrativa, na perspectiva bakhtiniana, procurando colocarnos em posição de escuta, compreendendo o sentido do enunciado articulado à vida. Trazemos as narrativas de si de alunos do ensino médio de um colégio federal localizado no Estado do Rio de Janeiro sobre suas experiências nas aulas de Educação Física. O gênero que se sobressaiu em suas enunciações foi a história em quadrinhos (HQ), em que os sujeitos falam sobre momentos marcantes vividos nas aulas desta disciplina, o que evidenciou a importância de estabelecer uma relação entre (inter)corporeidades e currículo escolar e a necessidade de repensar o ensino médio. Relacionamos o conceito de currículo oculto, segundo Jurjo Torres Santomé (2003), às enunciações dos sujeitos coautores dessa pesquisa que produziram narrativas e imagens inscritas em seus corpos - aqui entendidos como cronotopos e diálogos a partir de apropriações bakhtinianas de Susan Petrilli e Augusto Ponzio (2011) e Augusto Ponzio (2013; 2016). As narrativas de si são potentes, por exortarem uma pedagogia da escuta, possibilitando que narradores e escutadores se (trans)formem, realizando concretamente uma epistemologia outra da formação trazida pelas abordagens de histórias de vida e formação.

Palavras-chave: Educação Física. Currículo. Corpo.

\section{ABSTRACT IMAGES OF THE BODIES INSCRIBED IN THE NARRATIVES OF HIGH SCHOOL STUDENTS: THE (INTER) CORPOREALITY AND THE CURRICULUM}

This text is an exercise in feeling, thinking and acting other ways of dealing with research in education. We use the approach of narra- 
tive research in the Bakhtin perspective, trying to put ourselves in a position of listening, understanding the meaning of the articulated statement to life. We bring the narratives of themselves from high school students of a federal college in Rio de Janeiro about their experiences in Physical Education classes. The genre that stood out in its enunciations was comic strips (comics) in which the subjects talk about important moments lived in the classes of this discipline. This demonstrated the importance of establishing a relationship between (inter) corporeities and school curriculum and the need to rethink secondary education. The concept of hidden curriculum, according to Jurjo Torres, related to the enunciations of the subjects co-authors of this research produced narratives and images inscribed in their bodies - Here understood as chronotopes and dialogues from the Bakhtin appropriations of Susan Petrilli and Augusto Ponzio. The narratives of themselves are powerful because they exhort a pedagogy of listening, allowing narrators and listeners to (trans) form, concretely realizing an epistemology another of the formation brought by the approaches of stories of life and formation.

Keywords: Physical education. Curriculum. Body.

\section{IMÁGENES DE LOS CUERPOS INSCRITOS EN LAS}

\section{NARRATIVAS DE ALUMNOS DE LA ENSEÑANZA MEDIA:} LAS (INTER) CORPOREIDADES Y EL CURRÍCULO

Este texto es un ejercicio de sentir, pensar y actuar otros modos de lidiar con la investigación en la educación. Nos vemos del enfoque de investigación narrativa, en la perspectiva bakhtiniana, buscando ponernos en posición de escucha, comprendiendo el sentido del enunciado articulado a la vida. Traemos las narrativas de sí de alumnos de la escuela secundaria de un colegio federal de Río de Janeiro. El género que se sobresalió en sus enunciaciones fue la historia en cómics (HQs) en que los sujetos hablan sobre momentos marcados vividos en las clases de Educación Física. En cuanto a la relación entre (inter) corporeidades y currículo escolar vinculados a la necesidad de repensar la enseñanza media, articulamos currículo oculto, según Jurjo Torres, a las enunciaciones de los sujetos coautores de esa investigación cuyas narrativas traen imágenes inscritas en sus cuerpos - aquí entendidos como cronotopos Y diálogos a partir de apropiaciones bakhtinianas de Susan Petrilli y Augusto Ponzio. Las narrativas de sí son potentes por exhortar una pedagogía de la escucha, posibilitando que narradores y escuchadores si (trans) formen, realizando concretamente una epistemología otra de la formación 
traída por los abordajes de historias de vida y formación; las narrativas abarcan cuestiones singulares y al mismo tiempo sociales que componen los sujetos.

Palabras clave: Educación Física. Currículo. Cuerpo.

\section{Localizando as nossas intenções com esta escrita e a potência dos diálogos e das narrativas de si}

Nós construímos conhecimentos sempre na relação com os outros, no processo dialógico em que escutamos ativamente as enunciações de nossos interlocutores. E são as nossas interlocuções, escuta e resposta, que nos constituem professoras e professores mais potentes, porque atentas e atentos às relações alteritárias e seus deslocamentos, os quais são possíveis porque existem as/os estudantes, colegas professores e demais agentes educativos com os quais conversamos no território escolar espaço contínuo de formação acadêmico-profissional e também pessoal, porque formação humana.

Assim, as linhas que se seguem foram escritas pensando nos encontros com os agentes educativos nos espaços formativos em que (con)vivemos, incluindo então os diálogos com os colegas do GEPPROFI (Grupo de Estudos e Pesquisa de Processos de Formação Institucionais) e com os colegas e docentes de outros grupos e até mesmo de outras universidades, brasileiras e estrangeiras. Fazemos menção em especial aos diálogos e leituras realizados acerca das questões que envolvem o currículo com o professor Jurjo Torres Santomé, na Universidade de Coruña, na Espanha, em visita à Facultade de Ciencias da Educación, neste ano de 2017.

1 Tal receptividade se estendeu aos demais docentes, como Cathryn Teasley Severino (UDC, Espanha) e Montserrat Castro Rodríguez (UDC, Espanha); em especial ao encontro fortuito com a professora Gelta Terezinha Ramos Xavier (UFF, Brasil).
O coletivo GEPPROFI, coordenado pela professora Eda Maria de Oliveira Henriques (UFF), é um grupo que vem se dedicando a estudar a importância das abordagens (auto)biográficas na perspectiva das narrativas de histórias de vida e formação, bem como a sua relevância teórico-metodológica nas discussões de uma nova epistemologia da formação - também chamada de "epistemologia outra", 2 dialogando com inúmeros autores, tais como António Nóvoa e Mathias Finger (2010), Franco Ferrarotti (1988), Marie-Christine Josso (2004), Jerome Bruner (1988), Gaston Pineau e Jean-Louis Le Grand (2012), entre outros. Acreditamos que um grupo de estudos e pesquisa é também um importante círculo de cultura e um espaçotempo valorados, em que os sujeitos dialogam acerca de sua/nossa práxis, incluindo as maneiras éticas e estéticas de intervir no mundo.

Por acreditar na potência dos diálogos e das narrativas de si, trazemos as enunciações de alunas e alunos do ensino médio de um colégio da rede pública federal do Rio de Janeiro, em conversas entre os discentes e sua professora, que é uma das autoras deste texto. Para nós, a autoria aqui é compartilhada e procura trazer as subjetividades e singularidades dos

2 Preferimos a expressão “epistemologia outra”, por nos apropriarmos da filosofia da linguagem de Bakhtin que, ao discutir sobre a metodologia das ciências humanas, defende a perspectiva da heterociência, uma ciência outra capaz de pensar o objeto das ciências humanas: o sujeito expressivo e falante que compõe, em relação com o outro (com quem enuncia), uma arquitetônica da enunciação. 
sujeitos autores, sem deixar de abarcar, ainda que de maneira introdutória, a totalidade das características do coletivo em que as conversas foram realizadas. Isto significa dizer que os diálogos com os sujeitos, que têm como mote a relação entre (inter)corporeidades e currículo escolar, estão atrelados à necessidade de repensar o ensino médio.

Nesse sentido, caminhamos em consonância com Miguel Arroyo (2014), ao defender um outro protagonismo juvenil que possibilite incorporar novas dimensões do conhecimento capazes de nos permitir sistematizar as experiências sociais às indagações sobre essas experiências vividas (ARROYO, 2014, p. 55) pelos jovens, bem como a defesa de instituições públicas igualitárias que atendam as demandas dos mesmos em aspectos múltiplos da cultura, construção de conhecimentos e saberes distintos, entre outros. ${ }^{3}$

As narrativas que trazemos para a composição deste tecido estão no formato $\mathrm{HQ}$, isto é, são narrativas em quadrinhos, criadas por alunos do ensino médio de uma instituição pública federal, localizada no Estado do Rio de Janeiro. A iniciativa e a escolha do gênero, em que foram criadas tais narrativas, partiu dos próprios alunos; e a nossa preocupação, em princípio, foi de manter as maneiras singulares, únicas e irrepetiveis, com que os mesmos se expressaram. Escutar e responder ativamente

3 Em outro momento, as experiências vividas por uma das autoras deste texto serão mote para a discussão das diferenças entre instituições de ensino públicas, federais e estaduais. É gritante a discrepância entre as condições de trabalho vividas por um docente da rede pública estadual e por um docente de instituição pública federal. Diferenças em relação às condições de trabalho docente, planejamento pedagógico, espaço fisico de salas de aulas, acervo bibliográfico (há escolas estaduais que sequer possuem biblioteca), bem como diferenças salariais e de plano de carreira; são diferenças que interferem também no processo de ensino-aprendizagem dos estudantes e constroem um fosso que justifica a necessidade de pressões por instituições públicas mais igualitárias (ARROYO, 2014), niveladas, claro, pelo direito dos jovens à educação pública de qualidade, seu acesso e permanência. e de maneira compreensivo-responsiva, como nos auxilia a filosofia da linguagem de Mikhail M. Bakhtin (2012), são ações que nos orientam a sentir, pensar e agir, em uma perspectiva de escrita acadêmica outra e segundo uma outra pedagogia.

Nesse percurso de feitura de uma outra pedagogia e de uma escrita acadêmica também outra, construímos este texto, costurando diálogos com Bakhtin (2012) e o Círculo de Bakhtin, procurando cotejar com eles o corpo como valor cultural, no contexto da cronotopicalidade - do corpo entendido como cronotopo, espaço e tempo valorados, em que procuramos relacionar as narrativas dos estudantes (compreendidas como obras estéticas) como eventos no mundo (PONZIO, 2013, p. 42). A categoria intercorporeidade é permeada por tentativas de diálogo com Susan Petrilli e Augusto Ponzio (2011), ou seja, constrói-se na perspectiva da unidade da vida e, consequentemente, dos princípios da heterocientificidade - de uma ciência outra. Por essa razão, valemo-nos do entendimento da escrita e da imagem como eventos em enunciados narrativos em que 0 mundo teórico e o mundo da vida interagem no ato responsável do ser humano.

A história de vida é uma práxis sociolinguística particular, a qual representa o ponto culminante das mediações concretas que produziram o indivíduo ocupado em elaborar sua história e procurando, desse modo, articular narrativamente os diferentes movimentos que o fazem $\mathrm{e}$ o desfazem. Através da enunciação das mediações, a história de vida faz, portanto, emergir a céu aberto uma mina de saberes implícitos, de saberes práticos, concretos, experienciais, intimamente relacionados aos usos que thes deram origem. (PINEAU; LE GRAND, 2012, p. 144145)

Essas considerações de Gaston Pineau e Jean-Louis Le Grand (2012) a respeito das histórias de vida nos auxiliam a pensar de modo mais minucioso sobre as narrativas com as 
quais dialogamos, sobretudo por considerar que "fazer história de vida não é, por conseguinte, uma prática privada e insignificante" (PINEAU; LE GRAND, 2012, p. 145). Há interlocução qualitativa entre as singularidades, as particularidades dos sujeitos, e o social. Nas palavras dos autores, fazer história de vida é "uma prática que mobiliza grandes interesses públicos e que faz parte dos movimentos de reorganização social dos circuitos de produção e de difusão de saberes" (PINEAU; LE GRAND, 2012, p. 145).

Assim, ao pensar/tratar essa reorganização social mencionada acima, cotejamos com o referencial teórico-metodológico que alicerça/ costura este tecido: com Bakhtin, o trabalho de pesquisa em ciências humanas adquire "o diálogo infinito e inacabável em que nenhum sentido morre" (2003, p. 408). Na perspectiva bakhtiniana, não há álibi para se isentar da vida, das nossas ações responsáveis e responsivas (porque sempre em resposta às vozes que nos antecederam).

Nesse contexto não fragmentário, que repudia a ausência de sentidos e enfatiza a relação entre consciências valorativamente afirmadas, sujeitos expressivos e falantes, os estudos da corporeidade também não se distanciam da vida. Tratar da corporeidade é tratar da experiência do vivido, da relação entre diálogo e corpo: "Bakhtin ressalta particularmente a questão da encarnação da voz no corpo" (PONZIO, 2016, p. 302). A ideia, assim como a vida, é encarnada.

Bakhtin (2016) faz questão de evidenciar a participação direta do corpo na "palavra circunspecta" representada por Dostoiévski, as implicações, os efeitos registráveis na relação do herói com o próprio corpo, como consequência da palavra atenta, apesar dela, ao outro, não-indiferente ao outro. 0 próprio corpo, como resulta evidente, no caso do homem do subsolo, é privado de autossuficiência e de univocidade na interferência das vozes; o corpo não the pertence enquanto exposto ao olhar e à palavra do outro (PONZIO, 2016, p. 303). Interessa à teoria bakhtiniana um olhar para a vida, para os sujeitos expressivos e falantes, os quais enunciam porque possuem e são os seus corpos - a interação entre os sujeitos é corporal, por isso Ponzio (2016) afirma a importância de considerar os corpos envolvidos no diálogo.

Ponzio (2013) fala da arquitetônica baktiniana que vai pensar a vida a partir da estética da arte literária, caminho em que considera, em consonância com as enunciações bakhtinianas, que o ato é pensamento e também sentimento, sendo corpo compreendido como diálogo. Notemos que, ao falar de corpo, abarcamos as multiplicidades de corpos que dialogam, enquanto humanidades historicizadas. Em outras palavras, nessa tessitura, consideramos os corpos como "materialidades vivas" em que interagem pelo menos duas consciências, a do eu e a do outro.

O caminho que galgamos, então, considera as questões do corpo nas ciências humanas, procurando pensar a pesquisa vinculada à vida e compreendendo o corpo na trama intercorpórea, visto que o corpo é o sujeito que o encarna, sujeito sempre relacional. 0 trabalho com as narrativas de histórias de vida e formação, para nós, é construído por meio de um olhar exotópico e heterocientífico para o objeto das ciências humanas: o ser expressivo e falante, historicidade personalizada.

As historicidades personalizadas, os estudantes do ensino médio, trazem as suas concepções de corpo nas narrativas e nas imagens contidas nas histórias em quadrinhos que nos fazem identificar a relevância de pensarmos coletivamente as reflexões do currículo, sobretudo do currículo oculto, que encontramos nas enunciações dos sujeitos deste estudo. São discursos que trazem modos de ser na escola, 
modos de ser aluno 4 (tímido, problemático e conflitivo, imaturo, aplicado, ansioso, sobrevivente à escola). Cotejando com as ideias de Jurjo Torres Santomé (2003), identificamos que as narrativas desses estudantes podem proporcionar reflexões que se sustentam como estratégias, em que os estudantes saem da invisibilidade.

\section{Currículo, cultura escolar e intercorporeidade}

Hoje trago em meu corpo as marcas do meu tempo/ meu desespero a vida num momento/ a fossa, a fome, a flor, o fim do mundo.

(Taiguara)

Os estudos do currículo importam à pesquisa sobre/com a corporeidade na Educação Física escolar, por suscitarem ampliações do sentir/pensar/agir as práticas dos conteúdos da cultura corporal, sua sistematização, confrontos ideológicos e demais intervenções na práxis do professor. Tais ampliações se dão em vieses distintos, os quais se complementam e auxiliam a pensar o sistema educativo e, concomitantemente, a passagem dos jovens pelas instituições escolares. Atentamos, com Jurjo Torres Santomé (2003), a considerar tanto o currículo explícito ou oficial quanto o currículo oculto, sobretudo este último, por conter marcas significativas de alteridade e resistência:

O curriculum oculto costuma incidir no esforço dos conhecimentos, procedimentos, valores e expectativas mais de acordo com as necessidades e interesses da ideologia hegemônica desse momento sócio-histórico [...]. No entanto, o desenvolvimento do curriculum oculto nem sempre vai na direcção de uma consolidação dos interesses dos grupos sociais dominantes

4 Reflexões elaboradas por Torres Santomé (2003, p. 151-163). Neste capítulo, o autor trata do currículo oculto, mais especificamente da discriminação sexista nas instituições escolares - reflexões que parecem ser comuns à Espanha e ao Brasil. e das estruturas de produção e distribuição vigentes. A análise do curriculum latente em cada situação concreta põe em relevo que a vida dos estudantes nas escolas não se caracteriza por uma submissão sem mais aos ditados das normas, tarefas e significados que lhes impõem os seus docentes. Os alunos e alunas costumam resistir e alterar as mensagens a que a instituição os submete. (TORRES SANTOMÉ, 2015, p. 201)

As concepções, os discursos e as práticas marcam a nossa trajetória de vida e formação, porque deixam marcas no nosso corpo, em processos que são instituídos e também instituintes. Se há determinações da cultura hegemônica, há também resistências e alterações, por parte dos alunos, que são produzidas e também produzem o currículo oculto.

Nessa compreensão de currículo, em relação com a perspectiva da enunciação de Bakhtin (2012), o corpo e as imagens inscritas nas narrativas sobre os corpos são espaços de formação. Embora vida e pesquisa não sejam a mesma coisa, elas são uma unidade sob nossa responsabilidade, nossos atos responsáveis apreendidos em diálogo constante com a teoria bakhtiniana. Assim, inferimos que a pequena ideologia, segundo Bakhtin (2012), chamada também de ideologia do cotidiano, encontra ressonância nas análises de Torres Santomé (2003) a respeito do currículo oculto.

O curriculum crítico não só procura selecionar outros conteúdos culturais como forma de reconstruir o conhecimento de que a comunidade dispõe, como também se interessa pelas estratégias de ensino e aprendizagem que facilitam este processo de reflexão, de participação democrática e de exercício da responsabilidade e da solidariedade (TORRES SANTOMÉ, 2015, p. 203).

Considerar as questões da intercorporeidade no currículo da Educação Física corresponde a um movimento dialógico importante, o qual conflui no desenvolvimento dos processos educativos de uma sociedade democrática. Pro- 
cessos que podem favorecer "el desarrolho de todas las dimensiones de la personalidade de cada estudiante" (TORRES SANTOMÉ, 2015, p. 91).

Para tanto, importa alinhar o que planejamos às concretizações de nossas ideias encarnadas. E isto significa considerar aspectos múltiplos, que perpassam a organização dos conteúdos curriculares e sua relevância cultural, identificando o currículo "como una selección de la cultura realizada con el fin de posibilitar la comprensión del pasado y presente de nuestra comunidad y de sus lazos e interaciones con el resto de la humanidade"6 (TORRES SANTOMÉ, 2015, p. 91).

Jurjo Torres Santomé chama a atenção para o empecilho de uma filosofia educativa relacionada à agenda neoliberal, que não se ocupa das necessidades concretas das instituições e das idiossincrasias dos estudantes trabalhadores. Um currículo muito fechado, uniformizador e centralizado:

Se dicta una vuelta a un currículo y filosofia educativa más academicista y tradicional, pero com mayores controles para imponer y vigiar que realmente sea eficaz para los nuevos fines de construcción de personalidades neoliberais; de um nuevo sentido común que convierta en pensamento hegemónico las cosmovisiones positivistas y deshistorizantes que caracterizan al homo economicus, homo consumes y homo debitor. Um ser humano fuera de la historia, reducido y transformado em uma mercancia más.? (TORRES SANTOMÉ, 2015, p. 94)

5 "O desenvolvimento de todas as dimensões da personalidade de cada estudante". (TORRES SANTOMÉ, 2015, p. 91, tradução nossa)

6 "Como uma seleção da cultura realizada com a finalidade de possibilitar a compreensão do passado e do presente de nossa comunidade e seus laços e interações com o todo da humanidade". (TORRES SANTOMÉ, 2015, p. 91, tradução nossa)

7 "Dita-se um retorno a um currículo e filosofia educacional mais acadêmico e tradicional, mas com maiores controles para impor e monitorar que realmente seja eficaz para os novos propósitos da construção de personalidades neoliberais; de um novo senso comum que converte as visões mundanas positivistas e desistorizantes que caracterizam o homo economicus, o homo consome e o homo debitor no pensamento hegemônico. Um ser humano fora da história, redu-
O que inferir de uma educação e de um currículo escolar que não considera concretamente a intercorporeidade? Que formação corporal estamos desenvolvendo com os nossos jovens na escola básica? Estes questionamentos não podem ser exclusividade da Educação Física escolar, mas de todos os educadores comprometidos com a formação humana dos alunos. Todavia, em se tratando da Educação Física, como o trabalho pedagógico com as práticas corporais e os conteúdos da cultura corporal devem ser desenvolvidos? E o que se espera da Educação Física do ensino médio?

Se compreendemos que a ocupação com a formação corporal dos sujeitos não cabe apenas à Educação Física, identificamos a importância de um "currículo integrado", que interconecta as dimensões possiveis do conhecimento e da aprendizagem (TORRES SANTOMÉ, 2015, p. 102). Nesse contexto, vale ressaltar a defesa de Jurjo Torres Santomé de um "proyecto humano de conocer, de entender reflexivamente la realidade, el mundo"8 (TORRES SANTOMÉ, 2015, p. 101). Um projeto cuja responsabilidade é coletiva, em que estudantes e professores compõem uma verdadeira comunidade educativa.

Em conversa ${ }^{9}$ com o professor Jurjo Torres Santomé, da Universidade de Coruña, em fevereiro de 2017, foi evidenciada a relação estreita entre as questões da corporeidade e do "currículo oculto", cujas dimensões estão presentes em toda intervenção educativa, porém são dificeis de perceber. Esta é a temática de seu livro "El curriculum oculto" (TORRES SANTOMÉ,

zido e transformado em mais mercadorias". (TORRES SANTOMÉ, 2015, p. 94, tradução nossa)

8 "Projeto humano de conhecer, de entender reflexivamente a realidade, o mundo". (TORRES SANTOMÉ, 2015, p. 101)

9 A escrita deste item está em primeira pessoa do singular, pois a conversa com o professor Jurjo Torres Santomé, da Universidade da Coruña, foi com a primeira autora deste texto, cujas impressões compõem o referido item - construído em diálogo com a professora Eda Maria de Oliveira Henriques. 
2003), que procuro relacionar às questões da intercorporeidade na escola e, sobremaneira, à Educação Física escolar.

Assim, é olhando para a vida concreta, escutando os meus conversadores (alunas e alunos) que posso identificar melhor a relação entre intercorporeidade e "currículo oculto", comprometendo-me de fato com o intercâmbio das nossas relações e procurando um clima reflexivo e debates sinceros:

[...] es necesario que en las instituiciones escolares, las profesoras y profesores, como intelectuais comprometidos, generen un clima de reflexión y debate sincero, sin temores ni disimulos, acerca del porqué de los contenidos culturales con los que trabajan y como lo hacen; sobre qué dimensiones de la realidade, con qué fuentes y con qué metodologia facilitamos la reflexión de nuestros alumnos y alumnas, les permitimos comprender su realidad y les capacitamos para seguir analizando y poder intervir solidaria, democrática y eficazmente em las diversas esferas de la vida em su comunidade. ${ }^{10}$ (TORRES SANTOMÉ, 2003, p. 11)

As narrativas das histórias de vida e formação valorizam as trajetórias dos sujeitos, suas experiências, modos de sentir/pensar/agir no mundo concreto, de sujeitos coletivos, seres em devir e em diálogos intercorpóreos.

\section{Imagens dos corpos no currículo: o que contam os educandos?}

Quando a professora propôs às turmas do ensino médio que produzissem uma narrativa de suas histórias pessoais nas aulas de Educação

10 “[...] é necessário que, nas instituições escolares, as professores e os professores, como intelectuais comprometidos, gerem um clima de reflexão e debate sincero, sem medo ou dissimulação, sobre a razão dos conteúdos culturais com os quais eles trabalham e como eles o fazem; em que dimensões da realidade, com quais fontes e com a metodologia que facilitamos a reflexão de nossos alunos, permitimos que eles compreendam sua realidade e os capacitamos a continuar analisando e sendo capazes de intervir de forma solidária, democrática e efetiva nas diferentes esferas da vida em sua comunidade". (TORRES SANTOMÉ, 2003, p. 11, tradução nossa)
Física, considerando suas corporeidades (sentimentos, pensamentos e ações que marcaram as aulas na referida disciplina), seu único pedido era que o tipo textual fosse uma narrativa. A maioria dos alunos construiu narrativas em texto verbal e alguns educandos sugeriram, por conta própria, produções no gênero narrativas em quadrinhos.

A iniciativa dos próprios alunos de optar pelo gênero narrativas em quadrinhos, $H Q$, foi uma surpresa que nos incitou a pensar a composição estética do gênero escolhido e a voltar o nosso olhar às imagens dos corpos inscritas nessas narrativas, procurando ler em minúcia possiveis relações entre as (inter)corporeidades e o currículo escolar.

0 processo de leitura das imagens trazidas pelos educandos nos fez pensar nas considerações de Roger Chartier (2011) sobre o fato de que "o leitor, a partir de suas próprias referências, individuais ou sociais, históricas ou existenciais, dá um sentido mais ou menos partilhado aos textos de que se apropria" (CHARTIER, 2011, p. 20). Corroboramos sua afirmação de que ler aprende-se (CHARTIER, 2011, p. 21) e, ao nos apropriarmos da abordagem de pesquisa narrativa, na perspectiva bakhtiniana, identificamos a necessidade de realizar uma leitura compreensivo-responsiva das composições estéticas dos estudantes que aqui circulam suas vozes em coautoria conosco.

A teoria de Bakhtin (2012) nos auxilia a olhar para o cotidiano de maneira concomitantemente estética e ética, penetrando na unidade interna de sentido. Unidade que diz respeito ao processo de criação do artista, processo vinculado à vida do mesmo. "Arte e vida não são a mesma coisa, mas devem tornar-se algo singular em mim, na unidade da minha responsabilidade" (BAKHTIN, 2003, p. XXXIII). Na “interação arquitetônica entre outros valorativamente afirmados" (BAKHTIN, 2012, p. 143), respondemos ao outro com a nossa vida. $\mathrm{Na}$ 
filosofia da linguagem, Bakhtin (2012) afirma a participação do "eu" em diálogo com o "tu", inaugurando o que chamou de dever concreto do sujeito:

Esta participação assumida como minha inaugura um dever concreto: realizar a singularidade inteira como singularidade absolutamente não substituível do existir, em relação a cada momento deste existir. $E$ isso significa que esta participação transforma cada manifestação minha - sentimentos, desejos, estados de ânimo, pensamentos - em um ato meu ativamente responsável. (BAKHTIN, 2012, p. 118)

O sujeito concreto de Bakhtin (2012) é singular, responsável por estar inteiro nas relações, o que significa estar inteiro na vida. A polifonia, uma apropriação metafórica da área musical, em Dostoiévski, significa não somente a presença de muitas vozes no romance. Mas todas as vozes são plenivalentes e equipotentes, em perspectivas equivalentes e plenas. Nas narrativas de histórias em quadrinhos dos estudantes, a polifonia potencializa os processos formativos e a relação ensino-aprendizagem desses sujeitos e os nossos próprios, que somos formadores em construção.
Essa defesa da polifonia nos ajuda a romper com a unidade monológica do mundo, voltando-nos em amplitude e profundidade para a tarefa de construir um mundo polifônico, em que as vozes são independentes e autônomas. A postura responsável do sujeito da pesquisa aponta certos projetos de dizer que não podem ser moralizantes e muito menos monológicos: para haver condição de escuta ativa, os sujeitos dos discursos precisam estar inteiros nas relações.

\section{Narrativas com os corpos: inscrições em histórias em quadrinhos}

José é daqueles alunos esportistas que não perdem uma partida de futebol. Todas as atividades e exercícios pareciam não dar conta de sua energia. No entanto, não gostava muito quando o momento da aula era composto por debates ou quaisquer outras tarefas que fugiam à aula de Educação Física, como desenvolvimento da aptidão física: "agora eu uso toda a minha perseverança para retomar meu porte físico e viver tudo que eu não vivi".

\section{Enunciações corpóreas de/com José.}

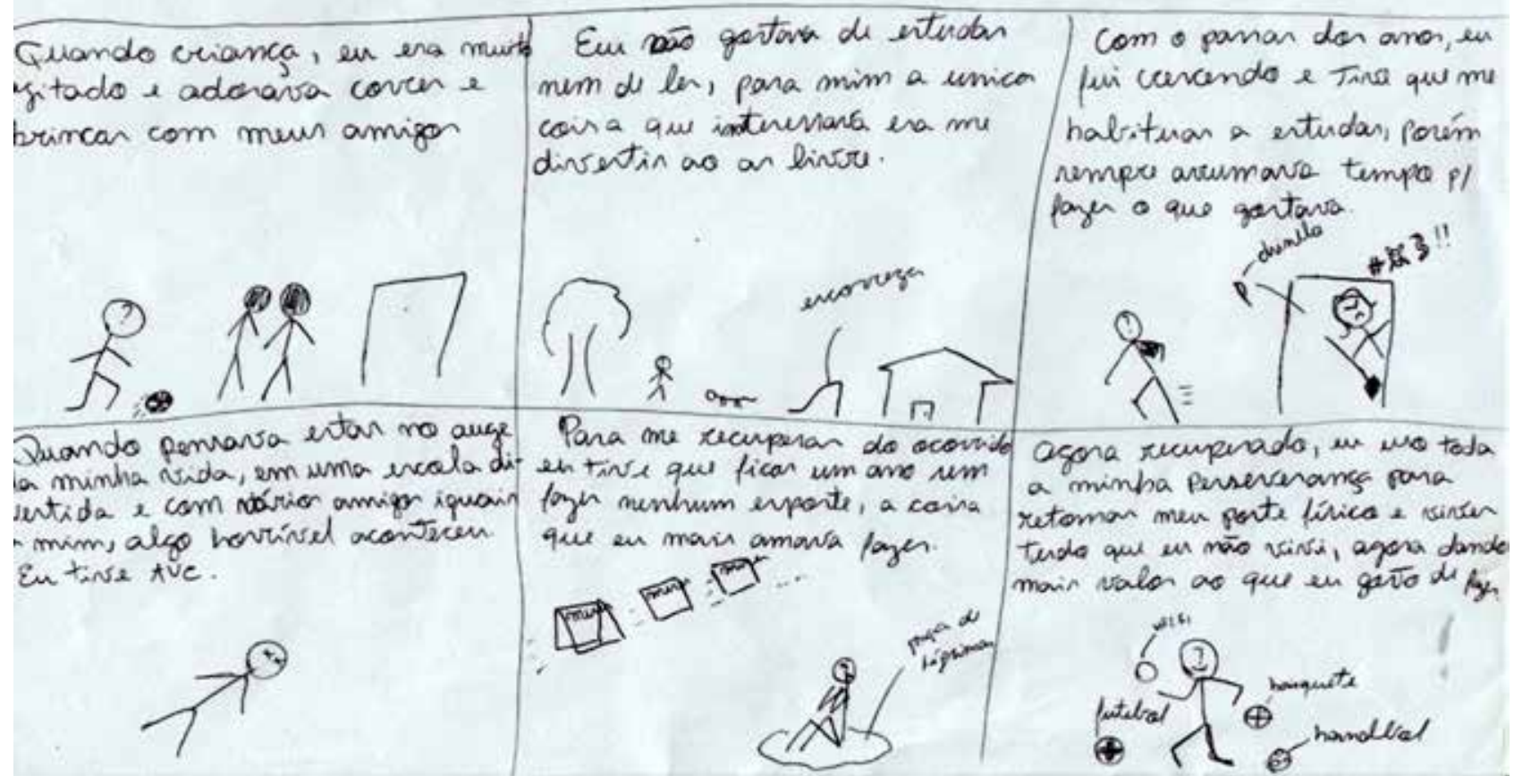


Viver, para José, é se exercitar, praticar esportes, ter uma boa aptidão física. Depois que sofreu um AVC (Acidente Vascular Cerebral), sua vida mudou consideravelmente. 0 médico cardiologista o proibiu de praticar exercícios físicos durante um tempo que, para ele, era interminável. Então, passou a realizar exercícios escondido dos pais. Sua preocupação com o desempenho era tão grande quanto sua habilidade para os jogos e os esportes. A habilidade motriz e social está refletida em algumas imagens da história em quadrinhos de José: em uma delas, em que o rapaz se encontra sozinho porque não pode realizar as práticas de atividade e exercício físicos, há um enorme pesar no discurso corroborado pela imagem de desolamento.

O sujeito concreto, expressivo e falante, José, impedido de frequentar as aulas de Educação Física, narra a problemática que foi ficar longe dos jogos e de quaisquer movimentos, por conta de um problema de saúde que requeria repouso total.

Ao associar exercício físico a desempenho, José levanta algumas concepções de Educação Física e de esportes, mais próximas da abordagem desenvolvimentista e militarista, em que valem mais o desenvolvimento motor e a aptidão física, em detrimento de um olhar mais reflexivo acerca da prática de ensino da referida disciplina. Podemos inferir que seus discursos às vezes dialogam com concepções de Educação Física em que predomina a ideia de um aperfeiçoamento físico permanente, em direção a uma competitividade não somente com o outro, mas consigo mesmo. Ainda que não seja o foco da disciplina escolar Educação Física, o treinamento para a aptidão física não é incomum à defesa de sua intervenção na prescrição de exercícios físicos visando à saúde de sujeitos ativos. ${ }^{11}$

11 Atualmente, há uma variedade de estudos e pesquisas na área da saúde com foco na aptidão física como a abordagem multidisciplinar. Neste texto, não iremos
É importante ressaltar que "a trajetória da educação e da educação física reforçou os valores da cultura eurocêntrica mediante a apresentação e afirmação dos saberes que a constituem" (NEIRA; UVINHA, 2009, p. 23). Por essa razão, o trabalho docente em Educação Física deve potencializar outras manifestações da cultura corporal, considerando as que foram postas à margem, como as manifestações corpóreas dos povos indígenas e dos negros. Uma pedagogia outra da Educação Física tem por premissa a participação de todos os estudantes, independentemente de suas habilidades, destreza e domínios corporais.

Uma Educação Física outra estaria pautada em uma diversificação dos conteúdos da cultura corporal bem como na ênfase da polifonia de vozes e corporeidades. Escutar melhor as enunciações de José passa pelo entendimento de influências contemporâneas no currículo da Educação Física, bem como por uma compreensão responsiva das falas levantadas por José e quaisquer outros alunos.

José traz questões inquietantes e caras à práxis do professor de Educação Física: não há um corpo; há corpos, sujeitos concretos em movimento, expressivos, ativos, desanimados, desejosos etc. No contexto vivenciado por José, percebemos que sua corporeidade enuncia suas angústias diante do impedimento, por questões médicas, de participar das aulas de Educação Física: o jovem apresenta em sua narrativa a infelicidade de não compor, com os demais colegas da turma, as aulas de Educação Física, em especial a prática esportiva, o futebol. A sua recuperação do AVC e, consequentemente, o seu retorno ao jogo significa

problematizar essa questão, todavia faz-se importante ressaltar que a saúde é um tema transversal que deve ser tratado na escola pelas disciplinas em geral, não sendo um conteúdo exclusivo da Educação Física. A Educação Física é uma prática pedagógica, cuja área de investigação/atuação é a cultura corporal, assim seus conteúdos são: jogos, lutas, danças, esportes, ginásticas etc. 
a volta às atividades prazerosas, que em suas palavras vão ao encontro de uma maior valorização do espaço-tempo do corpo em movimento.

O narrador José traz elementos para pensarmos onde estamos nós que não vemos ou não sabemos lidar com esses "corpos possíveis"? Nós, professoras e professores, que nem sempre sabemos lidar com as existencialidades? As aulas de Educação Física apresentaram-se monológicas para o jovem José, haja vista que ele não identificou outras dimensões e funções da disciplina. Não se trata de culpabilizar alguém, seja ele professor, aluno ou equipe gestora. Importa levar essas reflexões às rodas de conversa, deixando as palavras de todos circular e repensar as representações sobre o ensino-aprendizagem da Educação Física escolar:

Antes que os professores sejam responsabilizados pela hegemonia de certos conhecimentos nos currículos, convém recordar que, enquanto alunos da Educação Básica, dos cursos de Licenciatura ou mesmo da formação continuada, os docentes também construíram (e seguem construindo) representações acerca do ensino de Educação Física, ou seja, acessaram uma determinada identidade do componente. 0 que implicou na legitimação de saberes e formas de proceder. Basta observar, por exemplo, o predomínio de procedimentos didáticos que prometem a melhoria do desenvolvimento motor, cognitivo, afetivo-social ou a fixação de gestos considerados adequados pela cultura hegemônica. (NEIRA, 2011, p. 24-25)

As enunciações do aluno José, em cotejo com as considerações de Marcos Neira (2011) acerca do currículo de Educação Física e em diálogo com percepções bakhtinianas, nos levam a considerar as ações do currículo - neste caso o currículo da Educação Física - como capaz de "influenciar as formas de interpretar o mundo, interagir e comunicar ideias, além de sentimentos" (NEIRA, 2011, p. 25).
Falar de corpo em relação ao currículo é tratar de liberdade e aprisionamento, de dor e delícia, de marcas trazidas ao longo da história. Falar de corpo, por meio de narrativas (aqui as narrativas em quadrinhos), é falar de si, de histórias de vida e formação em que são enunciados atos, por vezes gozosos, por vezes sofridos. Que corpo sou? Que corpo estou? O que trago comigo e posso compartilhar com o outro? O que o outro compartilha comigo? O que só o outro pode dizer de mim? As indagações não se limitam a esse texto, elas transcendem os escritos aqui apresentados, embora essa construção polifônica traga a potência dos intercâmbios de saberes e reflexões sobre as nossas (trans) formações cotidianas na escola e fora dela. As enunciações de José podem trazer outras reflexões sobre as imagens inscritas em seu corpo e nos nossos corpos em relação - intercorporeidades.

As enunciações de Maria trazem às reflexões curriculares da escola, em especial sobre o currículo da Educação Física, questões que dizem respeito ao processo de ensino-aprendizagem e à construção do conhecimento, sendo refletidas e relacionadas à ideia de desempenho (acadêmico). Assim, atrelada ao desempenho, está a identificação da Educação Física como uma disciplina (talvez) menos importante ou mais ligada à noção de diversão e relaxamento: "embora no começo achasse que essa obrigatoriedade pudesse afetar o meu desempenho em outras matérias, depois percebi que só estudar não adiantava".

Ao escutar Maria, fica evidente a necessidade de chamar a atenção para o fato da disciplina Educação Física ser tão importante quanto as demais disciplinas escolares. Nas narrativas da estudante, a preocupação de que a Educação Física pudesse tirar o tempo de dedicação a outras disciplinas se constitui em uma concepção que foi/é construída pelo 
lugar que a Educação Física ocupa no currículo e, consequentemente, na estruturação da matriz curricular da escola, promovendo signifi- cações sobre o papel da referida disciplina e, consequentemente, da importância da relação corpo-mente no processo educativo.

\section{Enunciações corpóreas de/com Maria.}

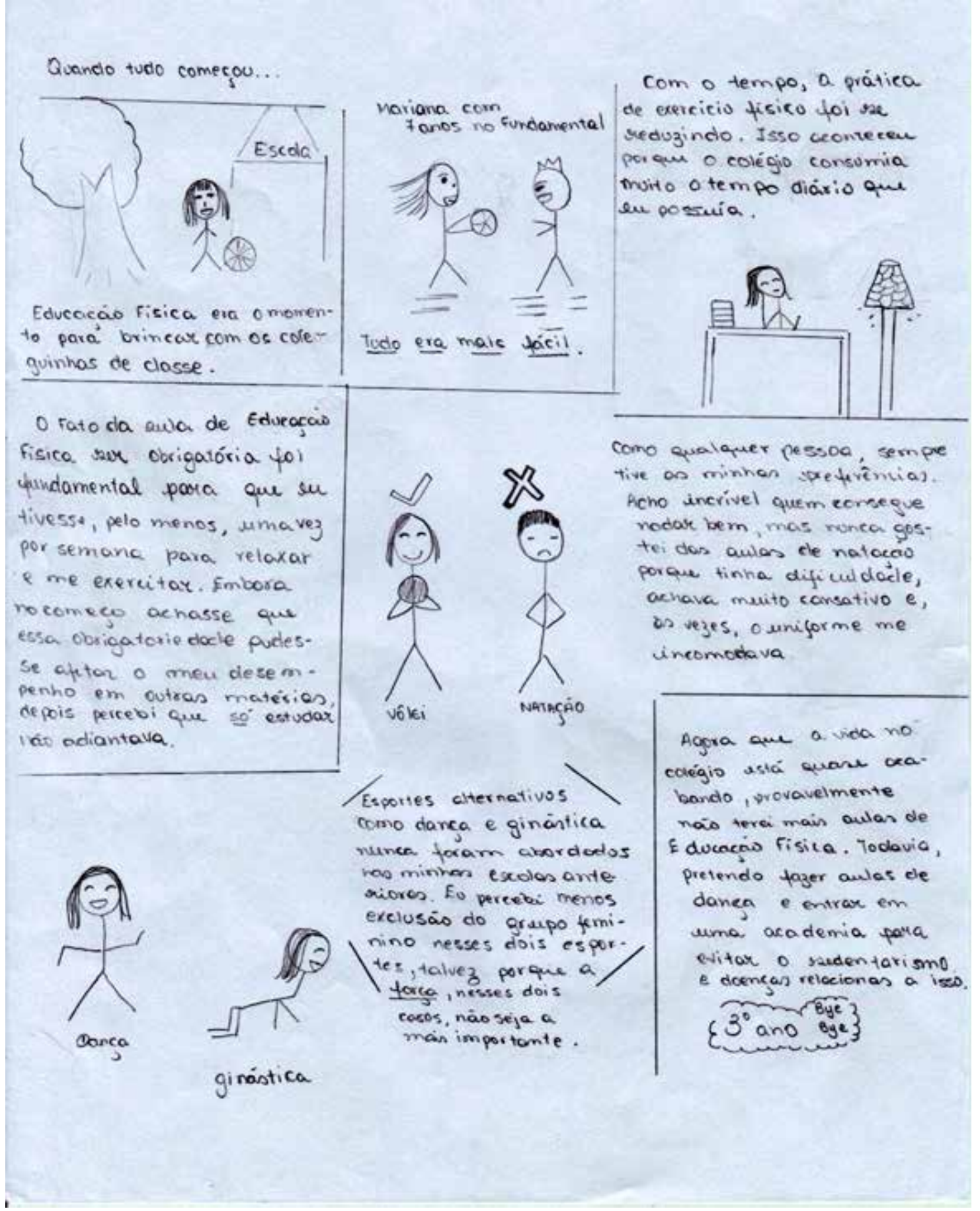

É interessante como a moça representa, nos desenhos, a dança e a ginástica, modalidades generificadas (aparecem como pertencentes a um determinado gênero, no caso o feminino), que não são questionadas por ela.
Assim, tal como na narrativa de José, Maria associa atividade e exercício físico ao desempenho, afirmando não se sentir bem em praticar atividades com o corpo nas quais não possa apresentar um bom desempenho. "Como qual- 
quer pessoa sempre tive as minhas preferências. Acho incrivel quem consegue nadar bem, mas nunca gostei das aulas de natação porque tinha dificuldades; achava muito cansativa e às vezes o uniforme me incomodava".

Escutar Maria nos remete à compreensão da arquitetônica bakhtiniana, que alicerça este nosso texto/tecido, que é um projeto de dizer baseado no processo de construção da metodologia narrativa de pesquisa em educação e Educação Física. Importa ressaltar que "a metodologia não é um método, mas um conjunto de métodos-como-percursos possíveis" (PRADO et al, 2015), sugerindo que não há uma única maneira de construir a pesquisa narrativa. Como sugere Heloísa Proença, "a metodologia narrativa lhe possibilita revisitar as experiências e compreender melhor o que o levou a determinadas ações. Com isso aprende mais sobre si, sobre o trabalho e pode vislumbrar outros percursos" (PRADO et al, 2015, p. 182). A autora aborda a "autoimplicação responsiva do pesquisador", e nos exorta a pensar os processos formativos narrados e apresentados nas pesquisas autobiográficas e suas potências, enquanto textos em que "o dever concreto é um dever arquitetônico" (BAKHTIN, 2012, p. 143), em que os acontecimentos são únicos e irrepetiveis entre o eu e o outro, sujeitos valorativamente afirmados, segundo Bakhtin (2012).

Assim, os nossos estudantes-narradores, Maria e José, dialogaram com as suas histórias em quadrinhos (HQ) e suas enunciações não se esgotam em nossa leitura/diálogo, pois a pesquisa narrativa e (auto)biográfica traz(em) a possibilidade de representação de um conjunto de dimensões da experiência que a investigação formal não considera e deixa de fora, além de trazer a importante questão do próprio processo de pesquisa poder constituir-se em uma experiência, na medida em que o pesquisador também se implica e se colo- ca como um sujeito da pesquisa, tornando-se mais um elo em uma comunidade de narrativas e de discursos (ou enunciações) suscitadas pelos outros sujeitos da pesquisa (BOLIVAR, 2014). Elos que se concluem temporariamente, podendo ser, inclusive, reconstruídos e ressignificados.

Assim, esta abordagem pretende compreender vários aspectos das histórias de vida e formação desses sujeitos, a partir de suas próprias referências, ao mesmo tempo singulares e sociais, permitindo a escuta de vozes silenciadas, a descoberta das sombras de cotidianos perdidos e de acontecimentos ignorados. Tal mudança de perspectiva traz muitos desafios teóricos e metodológicos, dos quais Bolivar (2014) destaca a questão epistemológica central da pesquisa (auto)biográfica, que consiste na legitimidade do conhecimento obtido a partir de experiências singulares e subjetivas, e na questão, apontada por Nóvoa (2010), ao mostrar a importância desse aporte para a busca e a possibilidade de uma nova epistemologia da formação.

\section{Considerações finais}

O processo de construção de conhecimentos é sempre relacional, entendendo a participação de pelo menos dois, duas consciências valorativamente afirmadas. Compreende também a importância de substituir o "eu" autocentrado pela relação eu-outro(s), pautada no ato responsável e responsivo de cada sujeito falante e expressivo. Nesse sentido, as conversas com o professor Jurjo Torres Santomé (UDC, Espanha) são tão importantes para as considerações que trouxemos nesta nossa escrita, quanto os textos publicados por ele.

De igual maneira, as narrativas de si dos alunos do ensino médio com os quais dialogamos demonstram a relevância da pesquisa narrativa na perspectiva bakhtiniana para sentir/pensar/agir ( $n$ )a formação de professores: 
as narrativas são potentes porque exortam uma pedagogia da escuta, possibilitando que narradores e escutadores se (trans)formem.

São inúmeras as contribuições da abordagem (auto)biográfica ao trabalho com as histórias de vida no campo de formação de professores, em que destacamos a possibilidade do diálogo inter e transdisciplinar, que suscita novas perspectivas de análise, compreensão e interpretação das narrativas. A perspectiva bakhtiniana potencializa e legitima a consistência do trabalho com as narrativas, sem contar que tal aporte contém em si uma mudança paradigmática, que reconduz o olhar para o sujeito, em sua singular complexidade social.

O currículo oculto produz certos discursos, neste caso específico sobre a Educação Física, sobre o corpo, sobre a relação do corpo com o processo educativo, sobre o próprio significado das atividades propostas, sobre maneiras de ser sexistas, práticas generificadas etc. Assim, em muitos aspectos, as enunciações contidas nas narrativas dos alunos dialogam com a produção de significados do currículo oculto.

Sem pretensões de impor uma única voz e com intenções de fazer girar e quem sabe rodopiar, galopear a prosa da vida..., arrematamos a costura deste tecido defendendo uma

\section{Referências}

ARROYO, Miguel G. Repensar o ensino médio por quê? In: DAYRELL, Juarez; CARRANO, Paulo; MAIA, Carla Linhares. (Orgs.). Juventude e ensino médio. Belo Horizonte: Editora UFMG, 2014. p. 157-203.

BAKHTIN, Mikhail. Arte e responsabilidade. In: Estética da criação verbal. São Paulo: Martins Fontes, 2003. p. XXXIII-XXXIV.

BAKHTIN, Mikhail. Para uma filosofia do ato responsável. São Carlos: Pedro \& João Editores, 2012.

BOLÍVAR, Antonio. A expressividade epistêmicometodológica da pesquisa (auto)biográfica. In: outra epistemologia da formação que priorize uma Educação Física outra, sem eugenia, corpolatria ou ditaduras quaisquer. Uma Educação Física que pense o corpo em sua pluralidade, que faça da aula momentos circenses, palco de muitas expressões, de corpos ativos, em sua plenitude, magros, gordos, esguios, baixos, de qualquer etnia, adaptados, readaptados... todos corpos sagrados, enunciando, por meio de narrativas, questões das trajetórias de vida e formação dos alunos com os quais dialogamos - aqui José e Maria. Eles narram e, ao narrar, reafirmam a importância do método (auto) biográfico como um caminho para produzir conhecimentos que ampliem a formação humana, articulando saberes teóricos aos saberes da vida cotidiana. O diálogo polifônico, em Bakhtin (2012), é potencializado nessas narrativas que articulam as relações dos sujeitos narradores com ou seus interlocutores, consigo mesmos e com a vida. As enunciações dos sujeitos narradores nos possibilitaram articular o currículo oculto à produção de determinados discursos e significações a respeito das concepções de corpo e formas de interpretar o mundo, interagir, comunicar ideias e sentimentos, bem como chamou a atenção para as várias dimensões que compõem a complexidade do processo formativo.

ABRAHÃO, Maria Helena Menna; BRAGANÇA, Inês Ferreira de Souza; ARAÚJO, Mairce da Silva. (Orgs.). Pesquisa (auto)biográfica, fontes e questões. Curitiba: CRV, 2014. p. 113-127.

BRAGANÇA, Inês. F. de Souza. Histórias de vida e formação de professores: diálogos entre Brasil e Portugal. Rio de Janeiro: EDUERJ, 2012.

BRUNER, Jerome. Desarrollo cognitivo y educación. Madrid: Ediciones Morata, 1988.

BUBNOVA, Tatiana. Do corpo à palavra: leituras bakhtinianas. São Carlos: Pedro \& João Editores, 2016. 
CHARTIER, Roger. Prefácio. In: CHARTIER, Roger. (Org.). Práticas da leitura. 5. ed. São Paulo: Estação Liberdade, 2011. p. 19-22.

DOMINICÉ, Pierre. O que a vida lhes ensinou. In: NÓVOA, António; FINGER, Matthias. (Orgs.). 0 método (auto)biográfico e a formação. Natal: EDUFRN; São Paulo: Paulus, 2010. p. 177-212.

FERRAROTTI, Franco. Sobre a autonomia do método biográfico. In: NÓVOA, António; FINGER, Matthias. (Orgs.). 0 método (auto)biográfico e a formação. Lisboa: Ministério da Saúde/Departamento de Recursos Humanos da Saúde/Centro de Formação e Aperfeiçoamento Profissional, 1988. p. 17-34.

JOSSO, Marie-Christine. Experiências de vida e formação. São Paulo: Cortez, 2004.

NEIRA, Marcos Garcia. Influências contemporâneas no currículo da Educação Física. In: NEIRA, Marcos Garcia. Educação Física. São Paulo: Blucher, 2011. p. 23-41.

NEIRA, Marcos Garcia; UVINHA, Ricardo Ricci. Cultura corporal: diálogos entre educação física e lazer. Petrópolis, RJ: Vozes, 2009.

NÓVOA, António; FINGER, Matthias. (Orgs.). 0 método (auto)biográfico e a formação. Natal: EDUFRN; São Paulo: Paulus, 2010.

PETRILLI; Susan; PONZIO, Augusto. Thomas Sebeok e os signos da vida. São Carlos: Pedro \& João Editores, 2011.

PINEAU, Gaston et al. As histórias de vida. Tradução de Carlos Eduardo Galvão Braga e Maria da Conceição Passeggi. Natal: EDUFRN, 2012.

PONZIO, Augusto. O cronótopo na obra de Bakhtin. In:______. Palavras e contrapalavras: circulando pensares do Círculo de Bakhtin. São Carlos: Pedro \& João Editores, 2013. p. 13-48.

PONZIO, Augusto. No Círculo com Mikhail Bakhtin. São Carlos: Pedro \& João Editores, 2016.

PRADO, Guilherme do Val Toledo; SERODIO, Liana Arrais. Metodologia narrativa de pesquisa em educação na perspectiva do gênero discursivo bakhtiniano. In: PRADO et al. (Orgs.). Metodologia narrativa de pesquisa em educação: uma perspectiva bakhtiniana. São Carlos: Pedro \& João Editores, 2015. p. 91-127.

TAIGUARA. Hoje. Intérprete: Taiguara. In: TAIGUARA. Hoje. [S. l.]: EMI-Odeon Brasil, 1969.

TORRES SANTOMÉ, Jurjo. El curriculum oculto. Madrid: Ediciones Morata, 2003.

TORRES SANTOMÉ, Jurjo. O curriculum oculto. Porto: Porto Editora, 2015.

Recebido em: 17.08.2017

Aprovado em: 05.11.2017

\footnotetext{
Roberta Jardim Coube é Doutoranda do Programa de Pós-Graduação em Educação da Universidade Federal Fluminense - UFF/bolsista CAPES. Grupo de Estudos e Pesquisa de Processos Institucionais de Formação (GEPPROFI) e Atos UFF Grupo de estudos bakhtinianos. e-mail: belcoube@hotmail.com
}

Rua Visconde de Itaboraí, 01, bloco 03, apto 1003, Ponta D’Areia, Niterói - RJ. 24030-090. Telefone: (21) 980892850 e (21) 965394074.

Eda Maria de Oliveira Henriques é Pós-Doutora pela Universidade de Aveiro, UA, Portugal. Professora do Programa de Pós-Graduação em Educação da Universidade Federal Fluminense (UFF). Coordenadora do Grupo de Estudos e Pesquisa de Processos Institucionais de Formação (GEPPROFI) - URL da Homepage: http//:www.uff.br. e-mail: edahenriques@gmail.com

Rua Prof. Marcos Valdemar de Freitas Reis, s/n, Bloco D, Campus do Gragoatá, Centro, Niterói - RJ. 24210 201. Telefone: (21) 999295883 / 25499464 